\title{
Multitasking by the OC Lineage during Bone Infection: Bone Resorption, Immune Modulation, and Microbial Niche
}

\author{
Philip M. Roper ${ }^{1}\left[\right.$, Christine Shao ${ }^{1}\left[\right.$ and Deborah J. Veis ${ }^{1,2,3, * \mathbb{C}}$ \\ 1 Division of Bone \& Mineral Diseases, Musculoskeletal Research Center, Washington University School of \\ Medicine, Saint Louis, MO 63110, USA; proper@wustl.edu (P.M.R.); shaochristine@wustl.edu (C.S.) \\ 2 Department of Pathology and Immunology, Washington University School of Medicine, \\ Saint Louis, MO 63110, USA \\ 3 Shriners Hospitals for Children, Saint Louis, MO 63110, USA \\ * Correspondence: dveis@wustl.edu; Tel.: +1-314-454-8472
}

Received: 2 September 2020; Accepted: 22 September 2020; Published: 24 September 2020

check for updates

\begin{abstract}
Bone infections, also known as infectious osteomyelitis, are accompanied by significant inflammation, osteolysis, and necrosis. Osteoclasts (OCs) are the bone-resorbing cells that work in concert with osteoblasts and osteocytes to properly maintain skeletal health and are well known to respond to inflammation by increasing their resorptive activity. OCs have typically been viewed merely as effectors of pathologic bone resorption, but recent evidence suggests they may play an active role in the progression of infections through direct effects on pathogens and via the immune system. This review discusses the host- and pathogen-derived factors involved in the in generation of OCs during infection, the crosstalk between OCs and immune cells, and the role of OC lineage cells in the growth and survival of pathogens, and highlights unanswered questions in the field.
\end{abstract}

Keywords: osteoclast; osteomyelitis; bone; Staphylococcus aureus; Porphyromonas gingivalis; neutrophil; macrophage

\section{Introduction}

As in other sites, the presence of pathogens in bone first elicits an innate immune response in which mature neutrophils and macrophages surround the invaders to form abscesses [1]. Staphylococcus (S.) aureus is the leading causative agent of infectious osteomyelitis (iOM) for most of the skeleton, except for iOM of the jaw related to periodontal diseases, where Porphyromonas (P.) gingivalis predominates [1,2]. A variety of other pathogens, however, are also capable of infecting bone [3-5]. The combined actions of the pathogens and host cells lead to high levels of many inflammatory cytokines, which expand the pool of osteoclast (OC) precursors and mature bone-resorbing cells. If the infection is not cleared by the immune system or medical treatment, with time, vascular compromise in infected tissue leads to necrotic areas of bone called sequestra that serve as a niche for chronic infection and incite further osteoclastic bone resorption [6]. In many cases, despite a robust immune response, bacteria can persist within sequestra, rendering patients generally incurable with antibiotics alone and in need of surgical intervention. As the site of hematopoiesis, bone is home to stem and progenitor populations as well as mature effector cells. Thus, given the variety of cells in this microenvironment, there is an opportunity for many factors to impact iOM pathogenesis. This review focuses on OCs as a specific node of host-pathogen interaction that has largely been overlooked except as a source of tissue damage and highlights this cell's potential to modify disease progression. 


\section{Homeostatic Osteoclastogenesis}

OCs are giant, multinucleated cells tasked with resorbing old or damaged bone as part of the homeostatic turnover needed to maintain proper skeletal health. They differentiate from immature myeloid progenitors primarily due to the actions of the osteoclastogenic cytokine receptor activator of NF-KB ligand (RANKL) [7-9]. Under normal physiological conditions, bone-forming osteoblasts and bone-residing osteocytes provide RANKL and supportive macrophage-colony stimulating factor (M-CSF), which drives commitment to the OC lineage and induces the fusion of these pre-OCs to form mature OCs. Osteoblast lineage cells also produce soluble RANKL decoy receptor osteoprotegerin (OPG), which creates the RANK/RANKL/OPG axis that regulates osteoclastogenesis. RANKL binding its receptor RANK initiates downstream signaling that is mediated by interaction between the adaptor protein TNF-receptor-associated factor 6 (TRAF6) and the cytoplasmic domain of RANK. The master transcription factor nuclear factor of activated T cells cytoplasmic 1 (NFATc1) is activated via a combination of immunoreceptor tyrosine-based activation motif (ITAM) co-receptor signaling and downstream activation of mitogen-activated protein kinases (MAPKs), nuclear factor- $\mathrm{kB}$ (NF- $\mathrm{kB}$ ), and activator protein 1 (AP-1). Early committed pre-OCs express tartrate-resistant acid phosphatase (TRAP) and $\alpha \mathrm{V} \beta 5$ integrin, whereas late precursors and mature OCs express cathepsin $\mathrm{K}$, calcitonin receptor, TRAP5b, and $\alpha \mathrm{V} \beta 3$ integrin. OCs, osteoblasts, and osteocytes form the bone multicellular unit and interact via tightly regulated signaling to properly maintain bone homeostasis.

\section{The Infectious Milieu, a Noxious Brew of Pathogen- and Host-Derived Factors Driving Osteoclastogenesis and Bone Resorption}

\subsection{Pathogen-Derived Factors and Pattern-Recognition Receptors}

Many bacteria produce lipoproteins and other products that bind pattern-recognition receptors (PRRs) such as Toll-like receptors (TLRs) [10,11], some of which are present on the plasma membrane of OC lineage cells (Figure 1). S. aureus activates TLR2 [12], whereas P. gingivalis can activate both TLR2 and TLR4 $[13,14]$. Other pathogenic products recognized by TLRs include double-stranded ribonucleic acid, heat-shock proteins, and flagellin that activate other TLRs $[10,15,16]$, and may work synergistically $[17,18]$. Fungi such as $C$. albicans can infect bone and activate TLRs and mannose receptors such as Dectin-1, which are also present on OC precursors $[19,20]$. Downstream signaling, including activation of MAPKs and NF- $\mathrm{KB}$, shares much in common with RANKL, but the outcome-at least in vitro-is contingent on the state of differentiation of the OC precursors. TLR agonists arrest OC differentiation when acting simultaneously with RANKL on uncommitted progenitors by interfering with NFATc1 induction, but such stimulation following previous RANKL exposure enhances osteoclastogenesis [10]. These effects parallel those of the inflammatory cytokine TNF $\alpha$ on RANKL-induced osteoclastogenesis, described below. In conditions where cell autonomous OC differentiation is inhibited, the primary effect of PRR activation is the production of pro-inflammatory cytokines such as TNF $\alpha$, interleukin (IL)-1 $\beta$, and IL-6, which can have paracrine osteoclastogenic effects [21]. The net effect of TLR-activating pathogenic factors in vivo is osteoclast-mediated bone loss in both human patients and animal models.

Another major pathway for microbial products to influence OC differentiation is via inflammasomes, which are very large complexes consisting of a receptor (such as nucleotide-binding oligomerization domain, leucine-rich repeat-containing protein 3 (NLRP3), or absent in melanoma 2 (AIM2)), the adaptor apoptosis-associated speck-like protein containing a CARD (ASC), and caspase-1 [22]. S. aureus and P. gingivalis can activate both NLRP3 and AIM2 [23-26], which leads to cleavage of pro-IL-1 $\beta$, pro-IL-18, and gasdermin-D, the pore-forming unit required for release of mature IL-1 $\beta$. Inflammasome activation in pre-OCs, either by microbial or host products, promotes OC differentiation and bone resorption in a cell-autonomous manner and contributes to the overall inflammatory milieu [27-30]. 


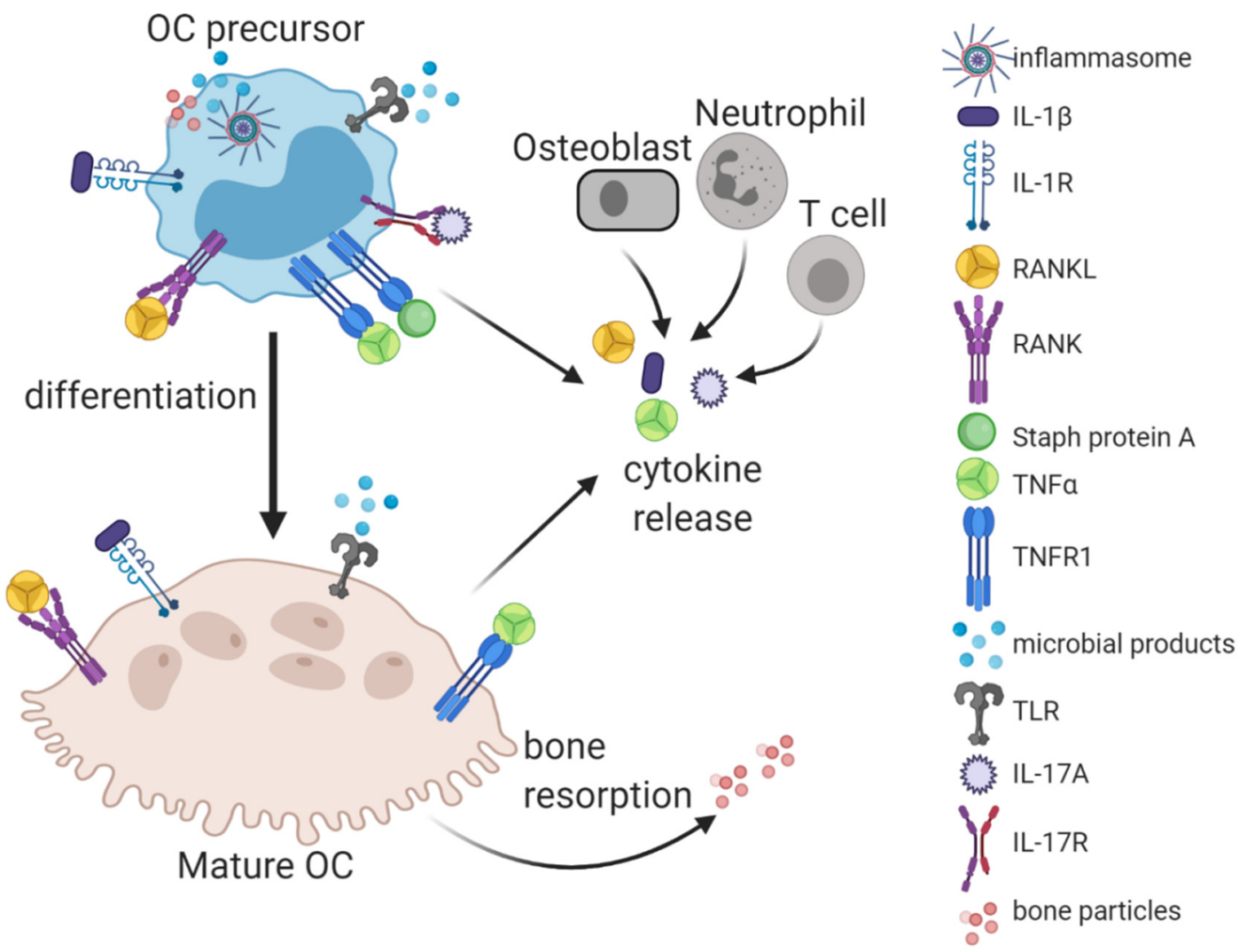

Figure 1. Osteoclastogenic and pro-resorptive factors in bone infection. Both OC precursors and mature OCs have numerous receptors (R), including inflammasomes, IL-1R, RANK, TNFR1, TLRs, and IL-17R, that allow them to respond to factors generated by both pathogens (staphylococcal protein $\mathrm{A}$ and other microbial products) and hosts (IL-1 $\beta$, RANKL, TNF $\alpha$, and IL-17A). Cytokines are released from many cells in the microenvironment including OC precursors and mature OCs, osteoblasts, neutrophils, and $\mathrm{T}$ cells. Bone necrosis and bone resorption can also generate microbial products and bone particles that activate the inflammasome and increase OC differentiation in concert with inflammatory cytokines.

The TLR and inflammasome responses to microbial products are not limited to the OC lineage during bone infection, but rather are activated in most cells, including non-OC myeloid cells and osteoblasts. This leads to high levels of IL-1 $\beta$ and other cytokines such as TNF $\alpha$, IL-6, and IL-17A that amplify the inflammatory milieu and have osteoclastogenic activity [31-35]. Osteoblasts also respond to microbial products through TLR and inflammasome pathways by upregulating RANKL and downregulating decoy receptor OPG, as well as releasing inflammatory cytokines [36-39].

Staphylococcal protein A, a molecule important to the microbe's ability to evade immune clearance, increases RANKL-induced OC differentiation via MAPK and NF- $\kappa B$ pathways $[40,41]$ perhaps by binding to TNFR1, which mediates its effects on osteoblasts [42,43]. Protein A can also form IgG immune complexes that act on the Fc receptor of pre-OCs to promote osteoclastogenesis through a TLR2/MyD88-dependent mechanism that signals to NFATc1 and NF-KB [44]. Without protein A, S. aureus does not promote bone loss in mice following intraperitoneal or calvarial inoculation [44]. These in vivo effects are likely both direct and indirect, as this virulence factor causes the release of IL-6 and RANKL from osteoblasts [42,45].

Another S. aureus factor, toxic shock syndrome toxin 1 (TSST-1), is a superantigen that functions to inhibit the immune response of host cells. TSST-1 is not cytotoxic, but enhances the bone resorption of mature OCs on mineralized matrix [46]. However, the mechanism for this effect has not been determined. S. aureus also makes an array of toxins, including phenol-soluble modulins (PSMs), that kill OCs as effectively as other cells such as monocytes and osteoblasts and are thus unlikely to 
have direct osteoclastogenic or pro-resorptive effects [46,47]. Nevertheless, loss of PSM $\alpha 1 / 2$ reduces bone loss in mice with $S$. aureus bone infections, although the cellular mechanism in vivo, whether via the survival of osteoblasts or the death of OCs, has not been determined [48].

$P$. gingivalis increases the osteoclastogenic potential of OC precursors both locally and systemically [49]. In addition to LPS-mediated TLR activation, P. gingivalis releases gingipains, cysteine proteases that can induce osteoclastogenesis of RANKL-treated OCs and enhance OC activity through an increase in integrin $\alpha \mathrm{v} \beta 3$ and degradation of OPG in co-culture with OBs [50,51]. Phosphoglycerol dihydroceramide, a distinctive ceramide of $P$. gingivalis, has also been found to promote RANKL-induced osteoclastogenesis. This unique lipid does not appear to work via either TLR or inflammasome recognition, but rather by interacting with nonmuscle myosin IIA and activating Rac [52].

\subsection{Cytokines and Other Host-Generated Osteoclastogenic Factors}

The signaling induced by many of the inflammatory cytokines produced during infection, including TNF $\alpha$, IL-6, IL-1 $\beta$, and IL-17A, share much in common with RANKL, including NF-KB and MAPKs. These factors enhance the OC differentiation of myeloid progenitors in the presence of RANKL $[21,33,35,53]$. The most intensively studied has been TNF $\alpha$, which has potent synergistic effects with RANKL. Although similar to TLR activation, it depends on the relative timing of the stimuli in vitro. Exposure of uncommitted progenitors to TNF $\alpha$ prior to or simultaneous with RANKL prevents OC differentiation, whereas even small amounts of RANKL before TNF $\alpha$ lead to robust osteoclastogenesis $[31,54]$. Early M-CSF was also discovered to have negative effects on osteoclastogenesis that are mitigated by culture on bone rather than plastic [55]. This calls into question the relevance of several of the in vitro studies on plastic that show inhibitory effects of TNF $\alpha$ and other inflammatory stimuli that seem to contradict the clear osteolytic actions of these cytokines in vivo.

IL-17A is a particularly potent osteoclastogenic cytokine induced by the action of TNF $\alpha$ on T cells. IL-17A stimulates the release of other inflammatory cytokines and RANKL from osteoblasts and synovial fibroblasts in rheumatoid arthritis [56-59] and is also induced during iOM and septic arthritis [60-62]. This factor, produced by the Th17 subset of CD4+ T cells, also induces RANK expression by OC progenitors [63]. TNF $\alpha$ acts on mesenchymal lineage cells to elicit IL-1 $\beta$ expression, which subsequently induces RANKL expression from the same mesenchymal lineage cells [33]. M-CSF, which is also required for osteoclastogenesis, is likewise upregulated by the action of TNF $\alpha$ on stromal cells [64]. Therefore, although several experimental models have demonstrated TNF $\alpha$-mediated osteoclastogenesis in the absence of RANK or RANKL $[35,54,65]$, their relevance to the context of infection, which induces a plethora of osteoclastogenic stimuli, including RANKL, is unclear.

Infection typically induces necrosis in bone, likely via vascular compromise. Host-derived damage-associated molecular patterns (DAMPs) emanating from dying cells contribute to PRR activation during infection. It was recently demonstrated in sterile models of osteocyte necrosis that macrophage-inducible $\mathrm{Ca}^{2+}$-dependent lectin receptor (MINCLE), an ITAM-associated PRR, drives osteoclastogenesis [66]. This mechanism is likely operative in the presence of pathogens as well. Other DAMPs, such as S100 proteins and high-mobility group box 1 (HMGB1), likely activate other PRRs and contribute additional osteolytic stimuli [67]. The bone matrix, in the form of hydroxyapatite particles, activates OCs via the inflammasome [29]. Purine metabolites are also released by osteocyte necrosis and have pro-resorptive activity. Adenosine diphosphate (ADP) promotes the activation of OCs through the P2RY12 receptor [68]. ATP bindsP2X7R, stimulating NF- $\mathrm{KB}$ and $\mathrm{PKC} / \mathrm{Ca}^{2+}$ signaling to induce osteoclastogenesis and Syk to promote resorption [69], as well as P2Y6R, which promotes OC survival [70]. Thus, a wide array of pathogen- and host-derived factors contribute to the recruitment and activation of OCs in the context of iOM (Figure 1). 


\section{Immune Modulation by OCs and Their Conventional and Unconventional Precursors}

\subsection{OC Precursors as Potential Immune Suppressors}

OCs differentiate from myeloid progenitors that overlap with cells known as myeloid-derived suppressor cells (MDSCs), a heterogeneous population of immature monocytes and granulocytes known for their immunosuppressive effects [71]. MDSCs are expanded and activated by a number of pro-inflammatory and infectious stimuli and inhibit $\mathrm{T}$ cells and innate immune functions of other myeloid cells via release of ROS, NO, and enzymes such as arginase-1 [71]. Several groups have shown that MDSCs can also differentiate into OCs and contribute to bone erosion in various noninfectious models [72-75], so they likely have the potential to cause tissue damage in iOM (Figure 2). In mouse models of prosthetic-associated S. aureus biofilms, MDSCs have been shown to accumulate at higher rates than neutrophils and macrophages, but their role in disease progression is likely complex. With S. aureus biofilms, MDSCs are partially responsible for bacterial persistence [76-78], whereas in the case of planktonic S. aureus, MDSCs can be beneficial in helping resolve acute infection [79]. One study using an in vitro human system of granulocytic MDSC production showed a reproducible biphasic response among many $S$. aureus strains, with low levels of enterotoxins causing MDSC expansion and higher levels inhibiting their proliferation [80]. In P. gingivalis infection, several subpopulations of MDSCs were induced and the $\mathrm{CD} 11 b^{+} \mathrm{Ly} 6 \mathrm{G}^{+} \mathrm{Ly} 6 \mathrm{C}^{\text {hi }}$ monocytic MDSCs were shown to suppress $T$ cell activation [81]. The generation and activation of MDSCs and their subsequent effect on iOM progression may also depend on pathogen-specific virulence factors and their local concentrations. Overall, much remains to be learned about the role of MDSCs in the context of bone infection, as it is not yet clear if they represent an important pool of OC progenitors that mediate tissue damage, whether they impair the immune response and contribute to bacterial persistence or proliferation beyond prosthesis-associated biofilms, or whether they can be beneficial and limit tissue damage without promoting the survival of pathogens.

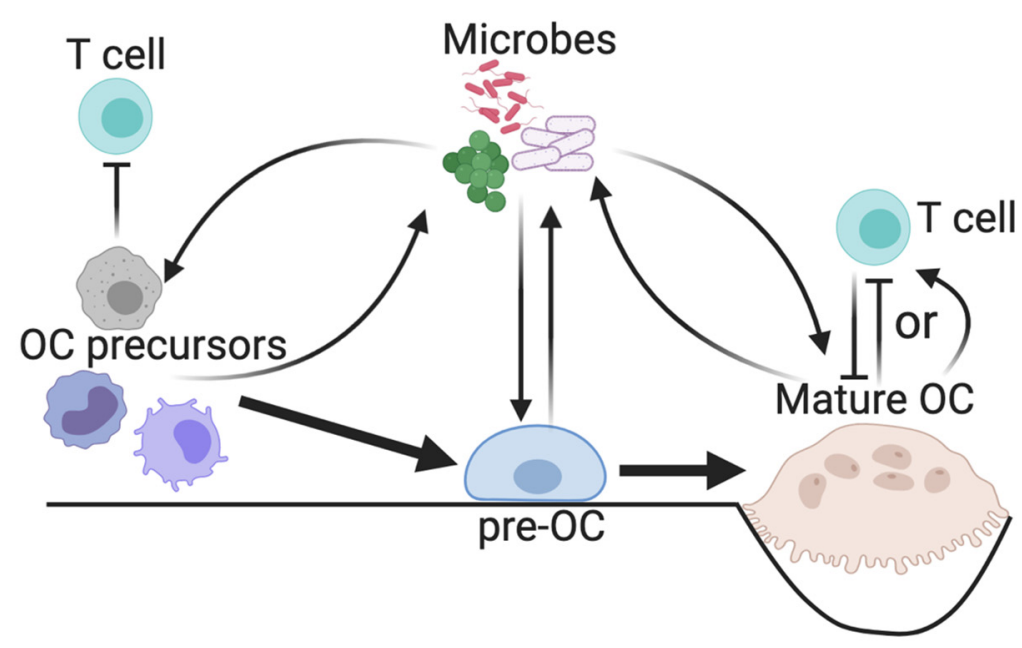

Figure 2. Relationship between microbes, OC lineage cells, and T cells. The presence of microbes in bone expands OC precursors, including the homeostatic monocytic precursors, those with myeloid-derived suppressor cell (MDSC) properties, and dendritic cells (DCs). Both MDSC-type OC precursors and mature OCs can inhibit pro-inflammatory T cell functions, whereas DC-derived OCs have been shown to enhance $\mathrm{T}$ cell activation. Whether the primary $\mathrm{OC}$ effect on $\mathrm{T}$ cells during infection is mainly inhibitory or pro-inflammatory has not yet been definitively demonstrated.

\subsection{Relationship between OCs, Dendritic Cells, and T Cells}

Although not a predominant pathway during bone homeostasis, several studies have shown that OCs can arise from dendritic cells (DCs) in pathological conditions [82]. Furthermore, transcriptionally, 
OCs seem to more closely mimic DCs than monocytes [82,83]. The demonstrated ability of OCs to present antigens to both CD4 and CD8 $\mathrm{T}$ cells places them firmly in the category of antigen-presenting cells [9], an activity compatible with ongoing bone resorption [84]. Several studies have also shown that $\mathrm{T}$ cells in bone marrow are most frequently found near OCs [85-87]. Many studies have shown that the priming of $\mathrm{T}$ cells that occurs via interaction with OCs preferentially polarizes them toward immunosuppressive regulatory states regardless of whether they express CD4 or CD8 (Treg and $\mathrm{T}_{\mathrm{C}}$ reg, respectively) [84,88-91] and that these regulatory $\mathrm{T}$ cells feed back on OCs to inhibit resorption. However, Ibáñez et al. also identified a minor subset of DC-derived OCs under chronic inflammatory conditions that produce high levels of inflammatory factors that, among other effects, enhance $\mathrm{T}$ cell activation [84]. Loss of cathepsin $\mathrm{K}$, a major bone-degrading enzyme released by OCs, inhibits inflammation in an infectious periodontitis model, although the dependence of this effect on OCs was not investigated [92,93]. Overall, the primary role of OCs during infection may be to enhance rather than suppress T cell-mediated inflammation (Figure 2). However, whether the adaptive antimicrobial response is affected by OCs via DC-like antigen presentation is still unclear. Further, it is not clear if the origin of OCs from DCs rather than monocytes in a disease state such as infection impacts their immunoregulatory or resorptive functions.

\section{Intracellular Infection of OCs Providing a Proliferative Niche}

Thus far, we have considered the response of OC lineage cells to pathogenic factors, as well as how this response affects immunity. However, a third way in which the OC can interact with pathogens is through intracellular infection. Several groups have demonstrated intracellular infection of osteoblasts by S. aureus (reviewed in [94]) as well as osteocytes [95,96]. Within these mesenchymal lineage cells, the bacteria persist but do not proliferate. Due to the long lifespan of osteoblasts, it has been proposed that these intracellular bacteria represent the seeds of persistent and recurrent infections. Recently, we showed that although OCs and their uncommitted myeloid progenitors take up S. aureus similarly, their handling of intracellular bacteria is quite different. OCs are not only unable to kill S. aureus, but also allow its intracellular proliferation, albeit with significant heterogeneity between cells [97] (Figure 3). Mycobacterium tuberculosis, an obligate intracellular pathogen capable of infecting bone, has also been found to proliferate within OCs to a much higher level than in precursors [98]. Finally, although data in primary cells is lacking, $P$. gingivalis can infect the macrophage cell line RAW-D and enhance its ability to form OCs after RANKL priming [99]. The behavior of $P$. gingivalis during this osteoclastogenic culture was not examined, so it is not clear whether it was able to proliferate. Nevertheless, it appears that intracellular infection of OCs by pathogens is not uncommon and the ability of these cells to restrain proliferation is limited. Furthermore, recent studies of $O C$ fate in vivo point to a much longer lifespan than previously thought [100], leaving open the possibility that OCs may not only provide an intracellular niche for pathogenic expansion during acute infection, but could also represent a long-term safe haven. 


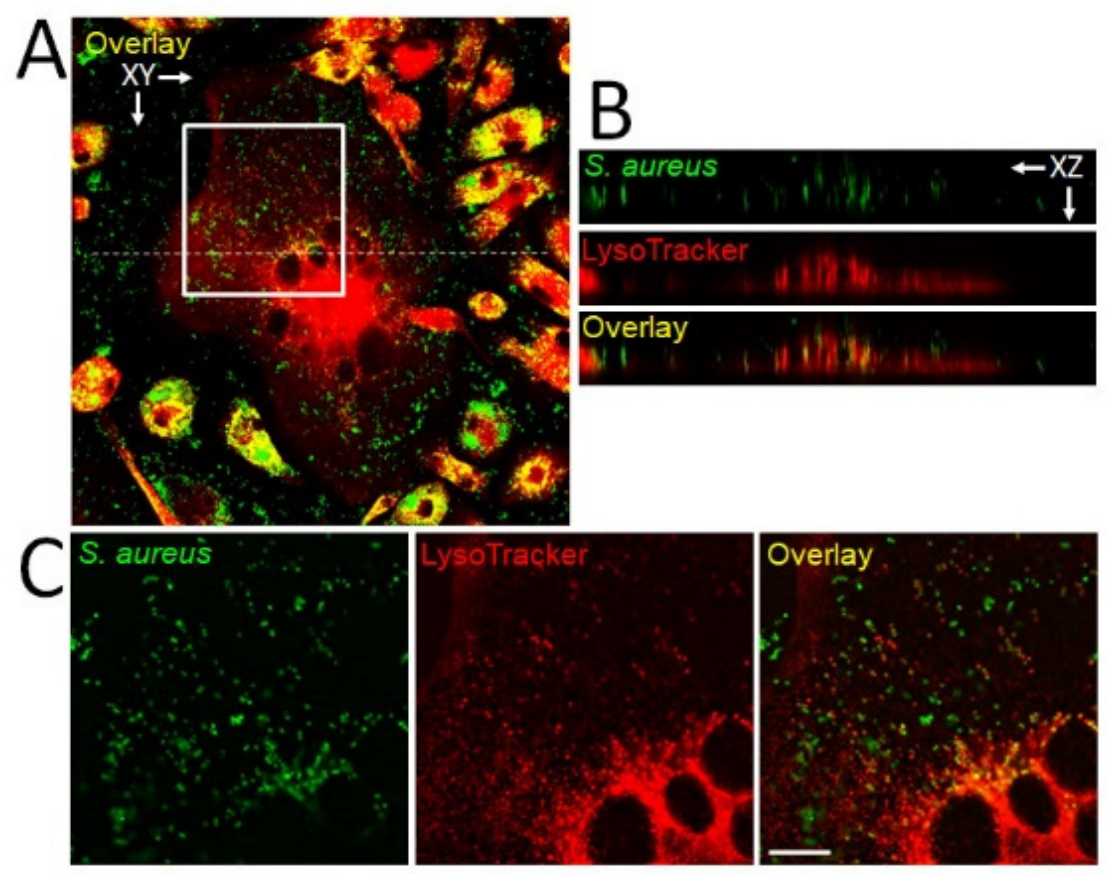

Figure 3. Internalization of $S$. aureus by mature OC and pre-OCs. Murine bone-marrow monocytes were differentiated in RANKL and M-CSF for 3 days, then infected with GFP-labeled S. aureus as previously described [97]. After $18 \mathrm{~h}$, cultures were fixed and stained with LysoTracker and imaged using a Nikon A1RSi confocal microscope and Nikon NIS-C Elements software. (A) Low-power image of a multinucleated OC surrounded by mononuclear pre-OCs in the XY plane. In this image, the degree of co-localization of bacteria (green) and lysosomes (red), indicated in yellow, is particularly variable in the pre-OCs, but similar variation occurs in OCs as well, as previously shown [97]. (B) Images in the $\mathrm{XZ}$ plane along the dotted line in (A) show that the bacteria are inside, rather than on top of, the OC. (C) XY plane images from the white box in A demonstrate only partial co-localization of bacteria and lysosomes in the mature OC. Scale bar, $10 \mu \mathrm{m}$. Microbes that avoid lysosomes are more likely to survive and proliferate than those that end up in these acidified vesicles.

\section{Clinical Implications}

Bone infections in patients can be divided into two major categories: those that occur in native bone and those associated with prostheses such as joint-replacement hardware, known as prosthetic joint infections (PJI). Although activation of OCs during bone infection has been well recognized in hematogenous or soft-tissue infection-associated $\mathrm{iOM}$, the problem of bone loss has largely been attributed to osteonecrosis due to a combination of vascular compromise and cytotoxicity. Therefore, targeting the OCs has not been seriously considered as a therapeutic approach. In the case of PJI, the role of neutrophils in the periprosthetic membrane in inducing OCs [101] is similar to the role of macrophages in the aseptic loosening of prostheses [102]. However, the presence of bacterial biofilms, which are resistant to antibiotics, has driven treatment paradigms that require mechanical debridement, replacement of hardware, and antibiotics, but not the specific targeting of other host factors such as OCs. Antiresorptive drugs have been successfully used in sterile forms of osteomyelitis, including chronic non-bacterial osteomyelitis and diffuse sclerosing osteomyelitis [103-105], as well as to reduce aseptic loosening of prosthetic joints [106]. These OC-targeting therapeutics have been implicated in cases of osteonecrosis of the jaw (ONJ), which is considered to be an entity separate from iOM of the jaw [107]. Although the pathophysiology of this type of medication-related ONJ remains poorly understood and exposure of bone to oral microflora may be involved [108-110], it is not at all clear that pathogens are significant drivers of ONJ, as they are not always detected histologically [111]. Infection of long bones or vertebrae is not listed as a potential complication of antiresorptive therapy [112]. Furthermore, early bisphosphonate treatment can mitigate bone loss in patients with vertebral osteomyelitis without 
any indications of worsening infection [113]. Therefore, there is no evidence that treatment of iOM patients with anti-OC therapies is likely to be detrimental. If OCs indeed promote both bacterial replication and inflammatory bone loss, it is possible that limiting their induction will be a beneficial adjunct to antibiotics. Notably, that RANKL targeting, such as with denosumab, is likely to be more useful than bisphosphonates since it prevents both osteoclastogenesis and bone resorption.

\section{Conclusions}

Bone infections are associated with increased OC differentiation and OC-mediated bone loss due to the direct actions of factors released by pathogens and the host's inflammatory response. In addition to the monocytic precursors that predominate during homeostasis, infectious conditions can expand non-traditional pools of OC precursors that include MDSCs and dendritic cells. Besides supplying additional bone-resorbing cells, the functions of these precursors may contribute to the inflammatory milieu or inhibit an adaptive immune response. Mature OCs may also produce cytokines and induce regulatory $\mathrm{T}$ cells that modulate the host response to infection. Finally, OCs, which can be long-lived in vivo, may represent an intracellular niche for bacterial persistence or proliferation, providing one more reason that infections in bone are sometimes difficult to eradicate. More research is needed to determine if therapeutic targeting of the OC can reduce the incidence of persistent and recurrent iOM.

Funding: P.M.R. was supported by National Institutes of Health (NIH)/National Institute of Arthritis and Musculoskeletal and Skin Diseases (NIAMS) T32AR060719. C.S. was supported by the Washington University Biology Summer Undergraduate Research Fellowship (Bio/SURF). D.J.V. was supported by NIH/NIAMS grants R21 AR073507 and R01 AR070030, and by the Shriners' Hospitals for Children grant 85117.

Acknowledgments: Figures 1 and 2 and the Graphical Abstract were created with BioRender.com. N.J. Pavlos of the School of Biomedical Sciences, University of Western Australia, Perth, Australia, provided the images in Figure 3, which have not been published elsewhere. We are grateful to G. Mbalaviele and A. Veis for critical reading of this manuscript.

Conflicts of Interest: The authors declare no conflict of interest.

\section{References}

1. Lew, D.P.; Waldvogel, F.A. Osteomyelitis. Lancet 2004, 364, 369-379. [CrossRef]

2. Barth, K.; Remick, D.G.; Genco, C.A. Disruption of immune regulation by microbial pathogens and resulting chronic inflammation. J. Cell. Physiol. 2013, 228, 1413-1422. [CrossRef] [PubMed]

3. Kremers, H.M.; Nwojo, M.E.; Ransom, J.E.; Wood-Wentz, C.M.; Melton, L.J., 3rd; Huddleston, P.M., 3rd. Trends in the epidemiology of osteomyelitis: A population-based study, 1969 to 2009. J. Bone Jt. Surg. Am. 2015, 97, 837-845. [CrossRef] [PubMed]

4. Goergens, E.; McEvoy, A.; Watson, M.; Barrett, I. Acute osteomyelitis and septic arthritis in children. J. Paediatr. Child Health 2005, 41, 59-62. [CrossRef]

5. Sendi, P.; Kaempfen, A.; Uçkay, I.; Meier, R. Bone and joint infections of the hand. Clin. Microbiol. Infect. 2020, 26, 848-856. [CrossRef]

6. Seebach, E.; Kubatzky, K.F. Chronic implant-related bone infections-can immune modulation be a therapeutic strategy? Front. Immunol. 2019, 10, 1724. [CrossRef]

7. Novack, D.V.; Mbalaviele, G. Osteoclasts-key players in skeletal health and disease. Microbiol. Spectr. 2016, 4 . [CrossRef]

8. Kumar, G.; Roger, P.M. From crosstalk between immune and bone cells to bone erosion in infection. Int. J. Mol. Sci. 2019, 20, 5154. [CrossRef]

9. Madel, M.B.; Ibáñez, L.; Wakkach, A.; de Vries, T.J.; Teti, A.; Apparailly, F.; Blin-Wakkach, C. Immune function and diversity of osteoclasts in normal and pathological conditions. Front. Immunol. 2019, 10, 1408. [CrossRef]

10. Souza, P.P.C.; Lerner, U.H. Finding a toll on the route: The fate of osteoclast progenitors after toll-like receptor activation. Front. Immunol. 2019, 10, 1663. [CrossRef]

11. Gu, Y.; Han, X. Toll-like receptor signaling and immune regulatory lymphocytes in periodontal disease. Int. J. Mol. Sci. 2020, 21, 3329. [CrossRef] [PubMed] 
12. Kim, J.; Yang, J.; Park, O.J.; Kang, S.S.; Kim, W.S.; Kurokawa, K.; Yun, C.H.; Kim, H.H.; Lee, B.L.; Han, S.H. Lipoproteins are an important bacterial component responsible for bone destruction through the induction of osteoclast differentiation and activation. J. Bone Miner. Res. 2013, 28, 2381-2391. [CrossRef] [PubMed]

13. Zhang, P.; Liu, J.; Xu, Q.; Harber, G.; Feng, X.; Michalek, S.M.; Katz, J. TLR2-dependent modulation of osteoclastogenesis by Porphyromonas gingivalis through differential induction of NFATc1 and NF-kappaB. J. Biol. Chem. 2011, 286, 24159-24169. [CrossRef] [PubMed]

14. Hajishengallis, G.; Sojar, H.; Genco, R.J.; DeNardin, E. Intracellular signaling and cytokine induction upon interactions of Porphyromonas gingivalis fimbriae with pattern-recognition receptors. Immunol. Investig. 2004, 33, 157-172. [CrossRef]

15. Hienz, S.A.; Paliwal, S.; Ivanovski, S. Mechanisms of bone resorption in periodontitis. J. Immunol. Res. 2015, 2015, 615486. [CrossRef]

16. Cao, F.; Zhou, W.; Liu, G.; Xia, T.; Liu, M.; Mi, B.; Liu, Y. Staphylococcus aureus peptidoglycan promotes osteoclastogenesis via TLR2-mediated activation of the NF-kB/NFATc1 signaling pathway. Am. J. Transl. Res. 2017, 9, 5022-5030.

17. Ishida, M.; Kitaura, H.; Kimura, K.; Sugisawa, H.; Aonuma, T.; Takada, H.; Takano-Yamamoto, T. Muramyl dipeptide enhances lipopolysaccharide-induced osteoclast formation and bone resorption through increased RANKL expression in stromal cells. J. Immunol. Res. 2015, 2015, 132765. [CrossRef]

18. Kishimoto, T.; Kaneko, T.; Ukai, T.; Yokoyama, M.; Haro, R.A.; Yoshinaga, Y.; Yoshimura, A.; Hara, Y. Peptidoglycan and lipopolysaccharide synergistically enhance bone resorption and osteoclastogenesis. J. Periodontal Res. 2012, 47, 446-454. [CrossRef]

19. Zhu, X.; Zhao, Y.; Jiang, Y.; Qin, T.; Chen, J.; Chu, X.; Yi, Q.; Gao, S.; Wang, S. Dectin-1 signaling inhibits osteoclastogenesis via IL-33-induced inhibition of NFATc1. Oncotarget 2017, 8, 53366-53374. [CrossRef]

20. Yamasaki, T.; Ariyoshi, W.; Okinaga, T.; Adachi, Y.; Hosokawa, R.; Mochizuki, S.; Sakurai, K.; Nishihara, T. The dectin 1 agonist curdlan regulates osteoclastogenesis by inhibiting nuclear factor of activated T cells cytoplasmic 1 (NFATc1) through Syk kinase. J. Biol. Chem. 2014, 289, 19191-19203. [CrossRef]

21. Mbalaviele, G.; Novack, D.V.; Schett, G.; Teitelbaum, S.L. Inflammatory osteolysis: A conspiracy against bone. J. Clin. Investig. 2017, 127, 2030-2039. [CrossRef] [PubMed]

22. Alippe, Y.; Mbalaviele, G. Omnipresence of inflammasome activities in inflammatory bone diseases. Semin. Immunopathol. 2019, 41, 607-618. [CrossRef]

23. de Andrade, K.Q.; Almeida-da-Silva, C.L.C.; Coutinho-Silva, R. Immunological pathways triggered by porphyromonas gingivalis and fusobacterium nucleatum: Therapeutic possibilities? Mediat. Inflamm. 2019, 2019, 7241312. [CrossRef] [PubMed]

24. Munoz-Planillo, R.; Franchi, L.; Miller, L.S.; Nunez, G. A critical role for hemolysins and bacterial lipoproteins in Staphylococcus aureus-induced activation of the Nlrp3 inflammasome. J. Immunol. 2009, 183, 3942-3948. [CrossRef] [PubMed]

25. Craven, R.R.; Gao, X.; Allen, I.C.; Gris, D.; Wardenburg, J.B.; McElvania-Tekippe, E.; Ting, J.P.; Duncan, J.A. Staphylococcus aureus alpha-hemolysin activates the NLRP3-inflammasome in human and mouse monocytic cells. PLoS ONE 2009, 4, e7446. [CrossRef]

26. Hanamsagar, R.; Aldrich, A.; Kielian, T. Critical role for the AIM2 inflammasome during acute CNS bacterial infection. J. Neurochem. 2014, 129, 704-711. [CrossRef]

27. Bonar, S.L.; Brydges, S.D.; Mueller, J.L.; McGeough, M.D.; Pena, C.; Chen, D.; Grimston, S.K.; Hickman-Brecks, C.L.; Ravindran, S.; McAlinden, A.; et al. Constitutively activated NLRP3 inflammasome causes inflammation and abnormal skeletal development in mice. PLoS ONE 2012, 7, e35979. [CrossRef]

28. Qu, C.; Bonar, S.L.; Hickman-Brecks, C.L.; Abu-Amer, S.; McGeough, M.D.; Pena, C.A.; Broderick, L.; Yang, C.; Grimston, S.K.; Kading, J.; et al. NLRP3 mediates osteolysis through inflammation-dependent and -independent mechanisms. FASEB J. 2015, 29, 1269-1279. [CrossRef]

29. Alippe, Y.; Wang, C.; Ricci, B.; Xiao, J.; Qu, C.; Zou, W.; Novack, D.V.; Abu-Amer, Y.; Civitelli, R.; Mbalaviele, G. Bone matrix components activate the NLRP3 inflammasome and promote osteoclast differentiation. Sci. Rep. 2017, 7, 6630. [CrossRef]

30. Kim, H.; Walsh, M.C.; Takegahara, N.; Middleton, S.A.; Shin, H.I.; Kim, J.; Choi, Y. The purinergic receptor P2X5 regulates inflammasome activity and hyper-multinucleation of murine osteoclasts. Sci. Rep. 2017, 7, 196. [CrossRef] 
31. Lam, J.; Takeshita, S.; Barker, J.E.; Kanagawa, O.; Ross, F.P.; Teitelbaum, S.L. TNF-alpha induces osteoclastogenesis by direct stimulation of macrophages exposed to permissive levels of RANK ligand. J. Clin. Investig. 2000, 106, 1481-1488. [CrossRef] [PubMed]

32. Zhang, Y.-H.; Heulsmann, A.; Tondravi, M.M.; Mukherjee, A.; Abu-Amer, Y. Tumor necrosis factor-a (TNF) stimulates RANKL-induced osteoclastogenesis via coupling of TNF type 1 receptor and RANK signaling pathways. J. Biol. Chem. 2001, 276, 563-568. [CrossRef] [PubMed]

33. Wei, S.; Kitaura, H.; Zhou, P.; Ross, F.P.; Teitelbaum, S.L. IL-1 mediates TNF-induced osteoclastogenesis. J. Clin. Investig. 2005, 115, 282-290. [CrossRef] [PubMed]

34. Ito, H.; Yamada, H.; Shibata, T.N.; Mitomi, H.; Nomoto, S.; Ozaki, S. Dual role of interleukin-17 in pannus growth and osteoclastogenesis in rheumatoid arthritis. Arthritis Res. Ther. 2011, 13, R14. [CrossRef]

35. O’Brien, W.; Fissel, B.M.; Maeda, Y.; Yan, J.; Ge, X.; Gravallese, E.M.; Aliprantis, A.O.; Charles, J.F. RANK-independent osteoclast formation and bone erosion in inflammatory arthritis. Arthritis Rheumatol. 2016, 68, 2889-2900. [CrossRef]

36. Marriott, I.; Hughes, F.M., Jr.; Bost, K.L. Bacterial infection of osteoblasts induces interleukin-1beta and interleukin-18 transcription but not protein synthesis. J. Interferon Cytokine Res. 2002, 22, 1049-1055. [CrossRef]

37. Alexander, E.H.; Rivera, F.A.; Marriott, I.; Anguita, J.; Bost, K.L.; Hudson, M.C. Staphylococcus aureus-induced tumor necrosis factor related apoptosis-inducing ligand expression mediates apoptosis and caspase-8 activation in infected osteoblasts. BMC Microbiol. 2003, 3, 5. [CrossRef]

38. McCall, S.H.; Sahraei, M.; Young, A.B.; Worley, C.S.; Duncan, J.A.; Ting, J.P.; Marriott, I. Osteoblasts express NLRP3, a nucleotide-binding domain and leucine-rich repeat region containing receptor implicated in bacterially induced cell death. J. Bone Miner. Res. 2008, 23, 30-40. [CrossRef]

39. Kassem, A.; Lindholm, C.; Lerner, U.H. Toll-like receptor 2 stimulation of osteoblasts mediates staphylococcus aureus induced bone resorption and osteoclastogenesis through enhanced RANKL. PLoS ONE 2016, 11, e0156708. [CrossRef]

40. Wang, Y.; Liu, X.; Dou, C.; Cao, Z.; Liu, C.; Dong, S.; Fei, J. Staphylococcal protein A promotes osteoclastogenesis through MAPK signaling during bone infection. J. Cell. Physiol. 2017, 232, 2396-2406. [CrossRef]

41. Ren, L.R.; Wang, H.; He, X.Q.; Song, M.G.; Chen, X.Q.; Xu, Y.Q. Staphylococcus aureus protein A induces osteoclastogenesis via the NF-кB signaling pathway. Mol. Med. Rep. 2017, 16, 6020-6028. [CrossRef] [PubMed]

42. Claro, T.; Widaa, A.; McDonnell, C.; Foster, T.J.; O’Brien, F.J.; Kerrigan, S.W. Staphylococcus aureus protein A binding to osteoblast tumour necrosis factor receptor 1 results in activation of nuclear factor kappa B and release of interleukin-6 in bone infection. Microbiology 2013, 159, 147-154. [CrossRef] [PubMed]

43. Bertelli, A.M.; Delpino, M.V.; Lattar, S.; Giai, C.; Llana, M.N.; Sanjuan, N.; Cassat, J.E.; Sordelli, D.; Gómez, M.I. Staphylococcus aureus protein A enhances osteoclastogenesis via TNFR1 and EGFR signaling. Biochim. Biophys. Acta 2016, 1862, 1975-1983. [CrossRef] [PubMed]

44. Kamohara, A.; Hirata, H.; Xu, X.; Shiraki, M.; Yamada, S.; Zhang, J.Q.; Kukita, T.; Toyonaga, K.; Hara, H.; Urano, Y.; et al. IgG immune complexes with Staphylococcus aureus protein A enhance osteoclast differentiation and bone resorption by stimulating Fc receptors and TLR2. Int. Immunol. 2020, 32, 89-104. [CrossRef] [PubMed]

45. Somayaji, S.N.; Ritchie, S.; Sahraei, M.; Marriott, I.; Hudson, M.C. Staphylococcus aureus induces expression of receptor activator of NF-kappaB ligand and prostaglandin E2 in infected murine osteoblasts. Infect. Immun. 2008, 76, 5120-5126. [CrossRef] [PubMed]

46. Flammier, S.; Rasigade, J.P.; Badiou, C.; Henry, T.; Vandenesch, F.; Laurent, F.; Trouillet-Assant, S. Human monocyte-derived osteoclasts are targeted by staphylococcal pore-forming toxins and superantigens. PLOS ONE 2016, 11, e0150693. [CrossRef]

47. Loughran, A.J.; Gaddy, D.; Beenken, K.E.; Meeker, D.G.; Morello, R.; Zhao, H.; Byrum, S.D.; Tackett, A.J.; Cassat, J.E.; Smeltzer, M.S. Impact of sarA and phenol-soluble modulins on the pathogenesis of osteomyelitis in diverse clinical isolates of staphylococcus aureus. Infect. Immun. 2016, 84, 2586-2594. [CrossRef]

48. Cassat, J.E.; Hammer, N.D.; Campbell, J.P.; Benson, M.A.; Perrien, D.S.; Mrak, L.N.; Smeltzer, M.S.; Torres, V.J.; Skaar, E.P. A secreted bacterial protease tailors the Staphylococcus aureus virulence repertoire to modulate bone remodeling during osteomyelitis. Cell Host Microbe 2013, 13, 759-772. [CrossRef] 
49. Cai, X.; Li, Z.; Zhao, Y.; Katz, J.; Michalek, S.M.; Feng, X.; Li, Y.; Zhang, P. Enhanced dual function of osteoclast precursors following calvarial Porphyromonas gingivalis infection. J. Periodontal Res. 2020, 55, 410-425. [CrossRef]

50. Yasuhara, R.; Miyamoto, Y.; Takami, M.; Imamura, T.; Potempa, J.; Yoshimura, K.; Kamijo, R. Lysine-specific gingipain promotes lipopolysaccharide- and active-vitamin D3-induced osteoclast differentiation by degrading osteoprotegerin. Biochem. J. 2009, 419, 159-166. [CrossRef]

51. Mo, W.; Luo, H.; Wu, J.; Xu, N.; Zhang, F.; Qiu, Q.; Zhu, W.; Liang, M. Gingipains promote RANKL-induced osteoclastogenesis through the enhancement of integrin $\beta 3$ in RAW264.7 cells. J. Mol. Histol. 2020, 51, 147-159. [CrossRef] [PubMed]

52. Kanzaki, H.; Movila, A.; Kayal, R.; Napimoga, M.H.; Egashira, K.; Dewhirst, F.; Sasaki, H.; Howait, M.; Al-Dharrab, A.; Mira, A.; et al. Phosphoglycerol dihydroceramide, a distinctive ceramide produced by Porphyromonas gingivalis, promotes RANKL-induced osteoclastogenesis by acting on non-muscle myosin II-A (Myh9), an osteoclast cell fusion regulatory factor. Biochim. Biophys. Acta Mol. Cell Biol. Lipids 2017, 1862, 452-462. [CrossRef] [PubMed]

53. Yokota, K.; Sato, K.; Miyazaki, T.; Kitaura, H.; Kayama, H.; Miyoshi, F.; Araki, Y.; Akiyama, Y.; Takeda, K.; Mimura, T. Combination of tumor necrosis factor $\alpha$ and interleukin- 6 induces mouse osteoclast-like cells with bone resorption activity both in vitro and in vivo. Arthritis Rheumatol. 2014, 66, 121-129. [CrossRef]

54. Zhao, B.; Grimes, S.N.; Li, S.; Hu, X.; Ivashkiv, L.B. TNF-induced osteoclastogenesis and inflammatory bone resorption are inhibited by transcription factor RBP-J. J. Exp. Med. 2012, 209, 319-334. [CrossRef]

55. De Vries, T.J.; Schoenmaker, T.; Aerts, D.; Grevers, L.C.; Souza, P.P.; Nazmi, K.; van de Wiel, M.; Ylstra, B.; Lent, P.L.; Leenen, P.J.; et al. M-CSF priming of osteoclast precursors can cause osteoclastogenesis-insensitivity, which can be prevented and overcome on bone. J. Cell. Physiol. 2015, 230, 210-225. [CrossRef]

56. Kotake, S.; Udagawa, N.; Takahashi, N.; Matsuzaki, K.; Itoh, K.; Ishiyama, S.; Saito, S.; Inoue, K.; Kamatani, N.; Gillespie, M.T.; et al. IL-17 in synovial fluids from patients with rheumatoid arthritis is a potent stimulator of osteoclastogenesis. J. Clin. Investig. 1999, 103, 1345-1352. [CrossRef]

57. Sato, K.; Suematsu, A.; Okamoto, K.; Yamaguchi, A.; Morishita, Y.; Kadono, Y.; Tanaka, S.; Kodama, T.; Akira, S.; Iwakura, Y.; et al. Th17 functions as an osteoclastogenic helper T cell subset that links T cell activation and bone destruction. J. Exp. Med. 2006, 203, 2673-2682. [CrossRef]

58. Shen, F.; Ruddy, M.J.; Plamondon, P.; Gaffen, S.L. Cytokines link osteoblasts and inflammation: Microarray analysis of interleukin-17- and TNF-alpha-induced genes in bone cells. J. Leukoc. Biol. 2005, 77, 388-399. [CrossRef]

59. Komatsu, N.; Takayanagi, H. Autoimmune arthritis: The interface between the immune system and joints. Adv. Immunol. 2012, 115, 45-71. [CrossRef]

60. Dey, I.; Bishayi, B. Impact of simultaneous neutralization of IL-17A and treatment with recombinant IL-2 on Th17-Treg cell population in S.aureus induced septic arthritis. Microb. Pathog. 2020, 139, 103903. [CrossRef]

61. Infante-Duarte, C.; Horton, H.F.; Byrne, M.C.; Kamradt, T. Microbial lipopeptides induce the production of IL-17 in Th cells. J. Immunol. 2000, 165, 6107-6115. [CrossRef]

62. Putnam, N.E.; Fulbright, L.E.; Curry, J.M.; Ford, C.A.; Petronglo, J.R.; Hendrix, A.S.; Cassat, J.E. MyD88 and IL-1R signaling drive antibacterial immunity and osteoclast-driven bone loss during Staphylococcus aureus osteomyelitis. PLoS Pathog. 2019, 15, e1007744. [CrossRef] [PubMed]

63. Adamopoulos, I.E.; Chao, C.C.; Geissler, R.; Laface, D.; Blumenschein, W.; Iwakura, Y.; McClanahan, T.; Bowman, E.P. Interleukin-17A upregulates receptor activator of NF-kappaB on osteoclast precursors. Arthritis Res. Ther. 2010, 12, R29. [CrossRef] [PubMed]

64. Kitaura, H.; Zhou, P.; Kim, H.J.; Novack, D.V.; Ross, F.P.; Teitelbaum, S.L. M-CSF mediates TNF-induced inflammatory osteolysis. J. Clin. Investig. 2005, 115, 3418-3427. [CrossRef]

65. Yao, Z.; Xing, L.; Boyce, B.F. NF-kappaB p100 limits TNF-induced bone resorption in mice by a TRAF3-dependent mechanism. J. Clin. Investig. 2009, 119, 3024-3034. [CrossRef]

66. Andreev, D.; Liu, M.; Weidner, D.; Kachler, K.; Faas, M.; Grüneboom, A.; Schlötzer-Schrehardt, U.; Muñoz, L.E.; Steffen, U.; Grötsch, B.; et al. Osteocyte necrosis triggers osteoclast-mediated bone loss through macrophage-inducible C-type lectin. J. Clin. Investig. 2020. [CrossRef]

67. Komori, T. Cell death in chondrocytes, osteoblasts, and osteocytes. Int. J. Mol. Sci. 2016, 17, 2045. [CrossRef] 
68. Su, X.; Floyd, D.H.; Hughes, A.; Xiang, J.; Schneider, J.G.; Uluckan, O.; Heller, E.; Deng, H.; Zou, W.; Craft, C.S.; et al. The ADP receptor P2RY12 regulates osteoclast function and pathologic bone remodeling. J. Clin. Investig. 2012, 122, 3579-3592. [CrossRef]

69. Dong, Y.; Chen, Y.; Zhang, L.; Tian, Z.; Dong, S. P2X7 receptor acts as an efficient drug target in regulating bone metabolism system. Biomed. Pharmacother. 2020, 125, 110010. [CrossRef]

70. Korcok, J.; Raimundo, L.N.; Du, X.; Sims, S.M.; Dixon, S.J. P2Y6 nucleotide receptors activate NF-kappaB and increase survival of osteoclasts. J. Biol. Chem. 2005, 280, 16909-16915. [CrossRef]

71. Gabrilovich, D.I.; Nagaraj, S. Myeloid-derived suppressor cells as regulators of the immune system. Nat. Rev. Immunol. 2009, 9, 162-174. [CrossRef]

72. Kirkwood, K.L.; Zhang, L.; Thiyagarajan, R.; Seldeen, K.L.; Troen, B.R. Myeloid-derived suppressor cells at the intersection of inflammaging and bone fragility. Immunol. Investig. 2018, 47, 844-854. [CrossRef] [PubMed]

73. Zhang, H.; Huang, Y.; Wang, S.; Fu, R.; Guo, C.; Wang, H.; Zhao, J.; Gaskin, F.; Chen, J.; Yang, N.; et al. Myeloid-derived suppressor cells contribute to bone erosion in collagen-induced arthritis by differentiating to osteoclasts. J. Autoimmun. 2015, 65, 82-89. [CrossRef] [PubMed]

74. Charles, J.F.; Hsu, L.Y.; Niemi, E.C.; Weiss, A.; Aliprantis, A.O.; Nakamura, M.C. Inflammatory arthritis increases mouse osteoclast precursors with myeloid suppressor function. J. Clin. Investig. 2012, 122, 4592-4605. [CrossRef] [PubMed]

75. Sawant, A.; Ponnazhagan, S. Myeloid-derived suppressor cells as osteoclast progenitors: A novel target for controlling osteolytic bone metastasis. Cancer Res. 2013, 73, 4606-4610. [CrossRef] [PubMed]

76. Heim, C.E.; Vidlak, D.; Scherr, T.D.; Kozel, J.A.; Holzapfel, M.; Muirhead, D.E.; Kielian, T. Myeloid-derived suppressor cells contribute to Staphylococcus aureus orthopedic biofilm infection. J. Immunol. 2014, 192, 3778-3792. [CrossRef]

77. Heim, C.E.; Vidlak, D.; Scherr, T.D.; Hartman, C.W.; Garvin, K.L.; Kielian, T. IL-12 promotes myeloid-derived suppressor cell recruitment and bacterial persistence during Staphylococcus aureus orthopedic implant infection. J. Immunol. 2015, 194, 3861-3872. [CrossRef]

78. Heim, C.E.; Vidlak, D.; Kielian, T. Interleukin-10 production by myeloid-derived suppressor cells contributes to bacterial persistence during Staphylococcus aureus orthopedic biofilm infection. J. Leukoc. Biol. 2015, 98, 1003-1013. [CrossRef]

79. Yamada, K.J.; Heim, C.E.; Aldrich, A.L.; Gries, C.M.; Staudacher, A.G.; Kielian, T. Arginase-1 Expression in Myeloid Cells Regulates Staphylococcus aureus Planktonic but Not Biofilm Infection. Infect. Immun. 2018, 86. [CrossRef]

80. Stoll, H.; Ost, M.; Singh, A.; Mehling, R.; Neri, D.; Schäfer, I.; Velic, A.; Macek, B.; Kretschmer, D.; Weidenmaier, C.; et al. Staphylococcal enterotoxins dose-dependently modulate the generation of myeloid-derived suppressor cells. Front. Cell. Infect. Microbiol. 2018, 8, 321. [CrossRef]

81. Su, L.; Xu, Q.; Zhang, P.; Michalek, S.M.; Katz, J. Phenotype and function of myeloid-derived suppressor cells induced by porphyromonas gingivalis infection. Infect. Immun. 2017, 85. [CrossRef]

82. Gallois, A.; Lachuer, J.; Yvert, G.; Wierinckx, A.; Brunet, F.; Rabourdin-Combe, C.; Delprat, C.; Jurdic, P.; Mazzorana, M. Genome-wide expression analyses establish dendritic cells as a new osteoclast precursor able to generate bone-resorbing cells more efficiently than monocytes. J. Bone Miner. Res. 2010, 25, 661-672. [CrossRef] [PubMed]

83. Kiesel, J.; Miller, C.; Abu-Amer, Y.; Aurora, R. Systems level analysis of osteoclastogenesis reveals intrinsic and extrinsic regulatory interactions. Dev. Dyn. 2007, 236, 2181-2197. [CrossRef]

84. Ibáñez, L.; Abou-Ezzi, G.; Ciucci, T.; Amiot, V.; Belaïd, N.; Obino, D.; Mansour, A.; Rouleau, M.; Wakkach, A.; Blin-Wakkach, C. Inflammatory osteoclasts prime TNF $\alpha$-producing CD4(+) T cells and express CX(3) CR1. J. Bone Miner. Res. 2016, 31, 1899-1908. [CrossRef] [PubMed]

85. Grassi, F.; Manferdini, C.; Cattini, L.; Piacentini, A.; Gabusi, E.; Facchini, A.; Lisignoli, G. T cell suppression by osteoclasts in vitro. J. Cell. Physiol. 2011, 226, 982-990. [CrossRef] [PubMed]

86. Kikuta, J.; Wada, Y.; Kowada, T.; Wang, Z.; Sun-Wada, G.H.; Nishiyama, I.; Mizukami, S.; Maiya, N.; Yasuda, H.; Kumanogoh, A.; et al. Dynamic visualization of RANKL and Th17-mediated osteoclast function. J. Clin. Investig. 2013, 123, 866-873. [CrossRef] [PubMed] 
87. Pöllinger, B.; Junt, T.; Metzler, B.; Walker, U.A.; Tyndall, A.; Allard, C.; Bay, S.; Keller, R.; Raulf, F.; Di Padova, F.; et al. Th17 cells, not IL-17+ $\gamma \delta$ T cells, drive arthritic bone destruction in mice and humans. J. Immunol. 2011, 186, 2602-2612. [CrossRef]

88. Kiesel, J.R.; Buchwald, Z.S.; Aurora, R. Cross-presentation by osteoclasts induces FoxP3 in CD8+ T cells. J. Immunol. 2009, 182, 5477-5487. [CrossRef]

89. Buchwald, Z.S.; Kiesel, J.R.; DiPaolo, R.; Pagadala, M.S.; Aurora, R. Osteoclast activated FoxP3+ CD8+ T-cells suppress bone resorption in vitro. PLoS ONE 2012, 7, e38199. [CrossRef]

90. Li, H.; Hong, S.; Qian, J.; Zheng, Y.; Yang, J.; Yi, Q. Cross talk between the bone and immune systems: Osteoclasts function as antigen-presenting cells and activate CD4+ and CD8+ T cells. Blood 2010, 116, 210-217. [CrossRef]

91. Fischer, L.; Herkner, C.; Kitte, R.; Dohnke, S.; Riewaldt, J.; Kretschmer, K.; Garbe, A.I. Foxp3(+) Regulatory T Cells in Bone and Hematopoietic Homeostasis. Front. Endocrinol. 2019, 10, 578. [CrossRef] [PubMed]

92. Hao, L.; Zhu, G.; Lu, Y.; Wang, M.; Jules, J.; Zhou, X.; Chen, W. Deficiency of cathepsin K prevents inflammation and bone erosion in rheumatoid arthritis and periodontitis and reveals its shared osteoimmune role. FEBS Lett. 2015, 589, 1331-1339. [CrossRef] [PubMed]

93. Hao, L.; Chen, J.; Zhu, Z.; Reddy, M.S.; Mountz, J.D.; Chen, W.; Li, Y.P. Odanacatib, A cathepsin K-specific inhibitor, inhibits inflammation and bone loss caused by periodontal diseases. J. Periodontol. 2015, 86, 972-983. [CrossRef] [PubMed]

94. Josse, J.; Velard, F.; Gangloff, S.C. Staphylococcus aureus vs. osteoblast: Relationship and consequences in osteomyelitis. Front. Cell. Infect. Microbiol. 2015, 5, 85. [CrossRef] [PubMed]

95. de Bentley, K.L.M.; Trombetta, R.; Nishitani, K.; Bello-Irizarry, S.N.; Ninomiya, M.; Zhang, L.; Chung, H.L.; McGrath, J.L.; Daiss, J.L.; Awad, H.A.; et al. Evidence of staphylococcus aureus deformation, proliferation, and migration in canaliculi of live cortical bone in murine models of osteomyelitis. J. Bone Miner. Res. 2017, 32, 985-990. [CrossRef]

96. Yang, D.; Wijenayaka, A.R.; Solomon, L.B.; Pederson, S.M.; Findlay, D.M.; Kidd, S.P.; Atkins, G.J. Novel insights into staphylococcus aureus deep bone infections: The involvement of osteocytes. mBio 2018, 9. [CrossRef]

97. Krauss, J.L.; Roper, P.M.; Ballard, A.; Shih, C.C.; Fitzpatrick, J.A.J.; Cassat, J.E.; Ng, P.Y.; Pavlos, N.J.; Veis, D.J. Staphylococcus aureus infects osteoclasts and replicates intracellularly. mBio 2019, 10. [CrossRef]

98. Hoshino, A.; Hanada, S.; Yamada, H.; Mii, S.; Takahashi, M.; Mitarai, S.; Yamamoto, K.; Manome, Y. Mycobacterium tuberculosis escapes from the phagosomes of infected human osteoclasts reprograms osteoclast development via dysregulation of cytokines and chemokines. Pathog. Dis. 2014, 70, 28-39. [CrossRef]

99. Kukita, A.; Ichigi, Y.; Takigawa, I.; Watanabe, T.; Kukita, T.; Miyamoto, H. Infection of RANKL-primed RAW-D macrophages with Porphyromonas gingivalis promotes osteoclastogenesis in a TNF- $\alpha$-independent manner. PLoS ONE 2012, 7, e38500. [CrossRef]

100. Jacome-Galarza, C.E.; Percin, G.I.; Muller, J.T.; Mass, E.; Lazarov, T.; Eitler, J.; Rauner, M.; Yadav, V.K.; Crozet, L.; Bohm, M.; et al. Developmental origin, functional maintenance and genetic rescue of osteoclasts. Nature 2019, 568, 541-545. [CrossRef]

101. Gaida, M.M.; Mayer, B.; Stegmaier, S.; Schirmacher, P.; Wagner, C.; Hansch, G.M. Polymorphonuclear neutrophils in osteomyelitis: Link to osteoclast generation and bone resorption. Eur. J. Inflamm. 2012, 413-426. [CrossRef]

102. Masters, E.A.; Trombetta, R.P.; de Mesy Bentley, K.L.; Boyce, B.F.; Gill, A.L.; Gill, S.R.; Nishitani, K.; Ishikawa, M.; Morita, Y.; Ito, H.; et al. Evolving concepts in bone infection: Redefining "biofilm", "acute vs. chronic osteomyelitis", "the immune proteome" and "local antibiotic therapy". Bone Res. 2019, 7, 20. [CrossRef] [PubMed]

103. Gross, C.; Weber, M.; Creutzburg, K.; Möbius, P.; Preidl, R.; Amann, K.; Wehrhan, F. Osteoclast profile of medication-related osteonecrosis of the jaw secondary to bisphosphonate therapy: A comparison with osteoradionecrosis and osteomyelitis. J. Transl. Med. 2017, 15, 128. [CrossRef]

104. Wan, J.T.; Sheeley, D.M.; Somerman, M.J.; Lee, J.S. Mitigating osteonecrosis of the jaw (ONJ) through preventive dental care and understanding of risk factors. Bone Res. 2020, 8, 14. [CrossRef] [PubMed]

105. AlDhalaan, N.A.; BaQais, A.; Al-Omar, A. Medication-related osteonecrosis of the jaw: A review. Cureus 2020, 12, e6944. [CrossRef] [PubMed] 
106. Ro, D.H.; Jin, H.; Park, J.Y.; Lee, M.C.; Won, S.; Han, H.S. The use of bisphosphonates after joint arthroplasty is associated with lower implant revision rate. Knee Surg. Sports Traumatol. Arthrosc. 2019, 27, 2082-2089. [CrossRef]

107. Kalyan, S.; Wang, J.; Quabius, E.S.; Huck, J.; Wiltfang, J.; Baines, J.F.; Kabelitz, D. Systemic immunity shapes the oral microbiome and susceptibility to bisphosphonate-associated osteonecrosis of the jaw. J. Transl. Med. 2015, 13, 212. [CrossRef]

108. Hansen, T.; Kunkel, M.; Weber, A.; Kirkpatrick, C.J. Osteonecrosis of the jaws in patients treated with bisphosphonates-histomorphologic analysis in comparison with infected osteoradionecrosis. J. Oral Pathol. Med. 2006, 35, 155-160. [CrossRef]

109. Rosen, H.N. Risks of Bisphosphonate Therapy in Patients with Osteoporosis; Post, T.W., Ed.; UpToDate: Waltham, MA, USA, 2020.

110. Kim, J.; Kim, S.W.; Lee, S.Y.; Kim, T.H.; Jung, J.H. Bone mineral density in osteoporotic patients with pyogenic vertebral osteomyelitis: Effect of early versus late treatment for osteoporosis. Osteoporos. Int. 2018, 29, 2761-2770. [CrossRef]

111. Hallmer, F.; Korduner, M.; Møystad, A.; Bjørnland, T. Treatment of diffuse sclerosing osteomyelitis of the jaw with denosumab shows remarkable results-A report of two cases. Clin. Case Rep. 2018, 6, 2434-2437. [CrossRef]

112. Otto, S.; Burian, E.; Troeltzsch, M.; Kaeppler, G.; Ehrenfeld, M. Denosumab as a potential treatment alternative for patients suffering from diffuse sclerosing osteomyelitis of the mandible-A rapid communication. J. Craniomaxillofac. Surg. 2018, 46, 534-537. [CrossRef] [PubMed]

113. Zhao, Y.; Ferguson, P.J. Chronic nonbacterial osteomyelitis and chronic recurrent multifocal osteomyelitis in children. Pediatr. Clin. N. Am. 2018, 65, 783-800. [CrossRef] [PubMed]

(C) 2020 by the authors. Licensee MDPI, Basel, Switzerland. This article is an open access article distributed under the terms and conditions of the Creative Commons Attribution (CC BY) license (http://creativecommons.org/licenses/by/4.0/). 